\title{
Hormonal modulation of mineral metabolism in reproduction
}

By C. J. Robinson, Judith Hall and S. O. Beshir, Department of Physiological Sciences, The Medical School, University of Newcastle upon Tyne, Newcastle upon Tyne $N E_{1}{ }_{7} R U$

Pregnancy and lactation present a considerable stress to calcium homoeostasis in mammals. This paper attempts to outline those mechanisms whereby the mother effects the appropriate alterations in $\mathrm{Ca}$ fluxes to respond to the increased $\mathrm{Ca}$ demands imposed by pregnancy and lactation, and to identify the factors, hormonal and otherwise, that contribute to the adaptative processes of pregnancy and lactation.

As there are considerable variations in the degree of Ca stress induced by such conditions and in the patterns of hormones that affect $\mathrm{Ca}$ metabolism in the various species, it is impossible to present a truly global review. The following discussion is, therefore, devoted largely to studies in the rat, with comparable observations on events occurring in man and ruminants included where appropriate. For a more complete review of mineral metabolism in ruminants, the recent Symposium of the Nutrition Society (Field, 1981 ; Gueguen \& Perez, I98I; Scott \& McLean, 198r) should be consulted.

\section{Extent of the alterations in $\mathrm{Ca}$ metabolism}

In humans, where the skeletal content of $\mathrm{Ca}$ is approximately $25 \mathrm{~mol}$, the normal $\mathrm{Ca}$ turnover is approximately $10 \mathrm{mmol} / \mathrm{d}$. The amount of $\mathrm{Ca}$ acquired by the foetus from its mother at term is of the order of $75^{\circ} \mathrm{mmol}$, the great majority of which is acquired over the last trimester (Pitkin, 1975); the subsequent lactational drain is of the order of $4-7.5 \mathrm{mmol} / \mathrm{d}$.

In the rat, whose total $\mathrm{Ca}$ content is approximately $60 \mathrm{mmol}$, approximately $4 \mathrm{mmol} \mathrm{Ca}$ are transferred to the litter by the time of parturition, the great majority in the last $7 \mathrm{~d}$ of pregnancy (Simkiss, 1967). However, up to $25 \mathrm{mmol} \mathrm{Ca}$ (equivalent to over $40 \%$ of the total maternal content of $\mathrm{Ca}$ ) may be transferred to the litter during the 3-week-period of lactation. Thus, whilst pregnancy poses a challenge to the $\mathrm{Ca}$ homoeostatic mechanism in these species, the challenge is considerably greater during lactation. Similar considerations apply for sheep (Braithwaite et al. 1969, 1970) cows (Simkiss, 1967) and pigs (Gueguen \& Perez, 1981).

Provided the dietary supply of $\mathrm{Ca}$ is adequate, there is little evidence of a reduction in mineral content of the maternal skeleton during pregnancy. Indeed, in both rats (Warnock \& Duckworth, 1944; Spray, 1950) and humans (Hummel et al. 1936) there appears to be deposition of a 'Ca reserve' (Simkiss, 1967). This indicates that the adaptations more than compensate for the mineral requirement 
of the maturing foetal skeleton, although evidence of a mineral deficit has been reported in the sheep (Braithwaite et al. 1970). Modest hypocalcaemia during pregnancy has been reported in humans, but when corrections are made for the hypoalbuminaemia associated with volume expansion, there is actually no significant alteration in the physiologically-important ionized Ca concentration (Pitkin, 1975).

Lactation presents a different picture. Here the extent of the alterations varies considerably from species to species. The Ca content of milk and the volume of milk produced (Table I), are important determinants of the $\mathrm{Ca}$ demand. They in turn are affected by the number of young to be suckled (from the human and cow who normally produce only one, to pigs and rats who frequently have litters in excess of ten) and the duration of lactation.

As the $\mathrm{Ca}$ requirement of lactation is much greater than that of pregnancy, it is not too surprising that modest hypocalcaemia and/or a loss of skeletal mineral are observed in a number of species including the rat (Warnock \& Duckworth, 1944), sheep (Braithwaite et al. 1969) and man (Atkinson \& West, 1970). There is also the acute post-partum hypocalcaemia of cows (Payne, I 964 ).

\section{Adaptative changes during pregnancy}

Ca metabolism may be altered primarily by:

(1) Deposition and resorption of $\mathrm{Ca}$ in the skeleton.

(2) The reabsorption of $\mathrm{Ca}$ by the kidney.

(3) The absorption of $\mathrm{Ca}$ from the gastrointestinal tract.

As indicated earlier, apart from instances of $\mathrm{Ca}$ deprivation, there is little evidence to suggest any diminution in the Ca content of the skeleton. Indeed, the evidence from rats and man would appear to indicate an increase rather than a decrease in skeletal $\mathrm{Ca}$ content during pregnancy.

A reduction in urinary $\mathrm{Ca}$ loss during pregnancy has been observed in humans (Goss, 1962), particularly during the last month of pregnancy (Heaney \& Skillman, 1971), whilst the plasma $\mathrm{Ca}$ concentration remains relatively constant. This implies some hormonal modulation of $\mathrm{Ca}$ retention, rather than a consequence of alterations in the filtered load of $\mathrm{Ca}$ (Nordin \& Peacock, 1969). However, the relatively small excretion of $\mathrm{Ca}$ in humans (a total of only $5 \mathrm{mmol} / \mathrm{d}$ ) would

Table I. Volume of milk produced and calcium content in various species*

$\begin{array}{lccc}\text { Species } & \begin{array}{c}\text { Ca content of milk } \\ (\mathrm{mmol} / \mathrm{l})\end{array} & \begin{array}{c}\text { Vol. of milk produced } \\ (\mathrm{l} / \mathrm{d})\end{array} & \begin{array}{c}\text { Total milk Ca } \\ (\mathrm{mmol} / \mathrm{d})\end{array} \\ \text { Rat } & 80 & 0.006-0.012 & 0.48-0.96 \\ \text { Human } & 8.25 & 0.35-0.8 & 2 \cdot 9-6.6 \\ \text { Sheep } & 40 & 0.3-1 \cdot 4 & 12-56 \\ \text { Pig } & 55 & 5.0-7.0 & 275-385 \\ \text { Cow } & 30 & 7 \cdot 0-24 \cdot 0 & 210-720\end{array}$

-Modified from Simkiss, 1967; Braithwaite et al. 1969; Baksi \& Anderson, 1971; Hart et al. 1978. 
preclude any marked contribution of the kidney to the $\mathrm{Ca}$ requirements of pregnancy, and even less to those of lactation.

Undoubtedly, the major site of adaptation is the gastrointestinal tract, where $\mathrm{Ca}$ absorption is frequently doubled (Heaney \& Skillman, 1971). This locus of Ca transport has the capacity to provide all the $\mathrm{C}_{\mathrm{a}}$ transported to the foetus via the placenta. That the increase in $\mathrm{Ca}$ absorption occurs is without question, what is not clear is the mechanism by which it is effected. In vitro studies (Schachter $e t$ al. 1960; Halloran \& DeLuca, 1980) indicate that the active transport of $\mathrm{Ca}$ is greatly increased in pregnant rats. Exactly which hormone or hormones contribute to this response will be discussed in the subsequent section. However, the possibility cannot be discounted that at least part of the increased absorption reflects intestinal hypertrophy which is associated with both pregnancy and lactation in rats (Craft, 1970) and mice (Harding \& Cairnie, 1975), as is the increase in mucosal surface area (Boyne et al. 1966). Whether these latter responses are directly hormonally mediated, or reflect induced hyperphagia, remains to be defined, as do their occurrence in ruminants and man.

\section{Possible hormonal mediators of the alterations in pregnancy}

Until 15 years ago, the only hormone believed to be involved in $\mathrm{Ca}$ homoeostasis in pregnancy was parathyroid hormone (PTH). However, a number of other hormones, including the lactogenic hormones, have now been implicated in the response.

Parathyroid hormone. PTH is elevated in late pregnancy in man (Cushard et al. 1972; Samaan et al. 1974; Retallack et al. 1977). Additionally, parathyroid hypertrophy has been observed in pregnant rats (Toverud et al. 1978) and cows (Capen et al. 1965). This latter observation may explain the chronic elevation of PTH levels in the presence of near-normal plasma Ca values.

PTH has three major actions (Robinson, 1974). It increases the tubular reabsorption of $\mathrm{Ca}$ in the kidney, it increases the resorption of $\mathrm{Ca}$ from the skeleton and it stimulates $\mathrm{Ca}$ absorption from the intestine. It would therefore follow that PTH is probably responsible for the reduction in urinary Ca (Goss, 1962; Heaney \& Skillman, 1971), although both prolactin and placental lactogen may also be involved (James et al. 1978; Makeen, 1980).

The action on the skeleton appears to be of little significance since most species, with the possible exception of sheep (Braithwaite et al. 1970), show an increase in skeletal $\mathrm{Ca}$ content in pregnancy, probably as a result of the increased calcitonin levels. However, in animals on a limited Ca ration, with relative hypocalcaemia, there is evidence of PTH-induced bone resorption (Bodansky \& Duff, 1941).

Since PTH stimulates intestinal Ca absorption (MacIntyre \& Robinson, I 969), probably by an effect on the synthesis of 1,25 -dihydroxy vitamin $\mathrm{D}_{3}\left(\mathrm{r}, 25(\mathrm{OH})_{2} \mathrm{D}_{3}\right)$ (Fraser \& Kodicek, 1973), the elevated levels of PTH seen in pregnancy undoubtedly contribute to the increased $\mathrm{Ca}$ absorption. However, studies in our laboratory have indicated that the elevation of $\mathrm{Ca}$ absorption in late pregnancy is 
little influenced by the absence of the parathyroid glands, suggesting that they are not the major influence.

${ }_{1,25}(\mathrm{OH})_{2} D_{3}$. This is the major active metabolite of vitamin D and, like PTH, it has three actions, on bone, kidney and the intestine. The resorption of bone is only seen with very high levels of $1,25(\mathrm{OH})_{2} \mathrm{D}_{3}$ and the effects on the renal handling of $\mathrm{Ca}$ are small and controversial (Pushett et al. 1974; Bonjour et al. 1978).

$1,25(\mathrm{OH})_{2} \mathrm{D}_{3}$ levels are significantly elevated at the end of pregnancy (Table 2 , Halloran \& DeLuca, I980). How much of the elevated $1,25(\mathrm{OH})_{2} \mathrm{D}_{3}$ is of renal origin and how much is synthesized in the placenta (Weisman et al. 1979) remains to be established. However, $\mathrm{I}, 25(\mathrm{OH})_{2} \mathrm{D}_{3}$ is probably responsible for much of the increase in $\mathrm{Ca}$ absorption seen at this time as it is an extremely potent stimulator of Ca transport (Norman, 1978) and is probably the common pathway through which a number of hormones exert their effect upon $\mathrm{Ca}$ absorption. Experiments are in progress in our laboratory to attempt to determine in vivo that proportion of the increase in $\mathrm{Ca}$ absorption due to $\mathrm{r}, 25(\mathrm{OH})_{2} \mathrm{D}_{3}$ and that due to the increase in surface area of the intestine (Craft, 1970) during pregnancy and lactation.

Prolactin. This is primarily considered to be a lactogenic hormone although it is now known that it has many other actions. Not least among these is that it exerts an effect on Ca metabolism in terms of Ca retention by the kidney (Makeen, I 980) and the stimulation of $\mathrm{Ca}$ transport both in vitro (Mainoya, 1975) and in vivo (James et al. 1977). The latter effect is mediated largely by an action on the synthesis of $1,25(\mathrm{OH})_{2} \mathrm{D}_{3}$ (Spanos et al. 1976). Prolactin also increases feeding drive (C. J. Robinson and D. Stephenson, unpublished results) and fluid intake in the rat (Kaufman, I98I) and thus may increase the amount of $\mathrm{Ca}$ available for absorption.

Table 2. Effects of bromocriptine ( $0.5 \mathrm{mg}$ twice daily for $3 \mathrm{~d}$ ) in rats

(Mean values with their standard errors)

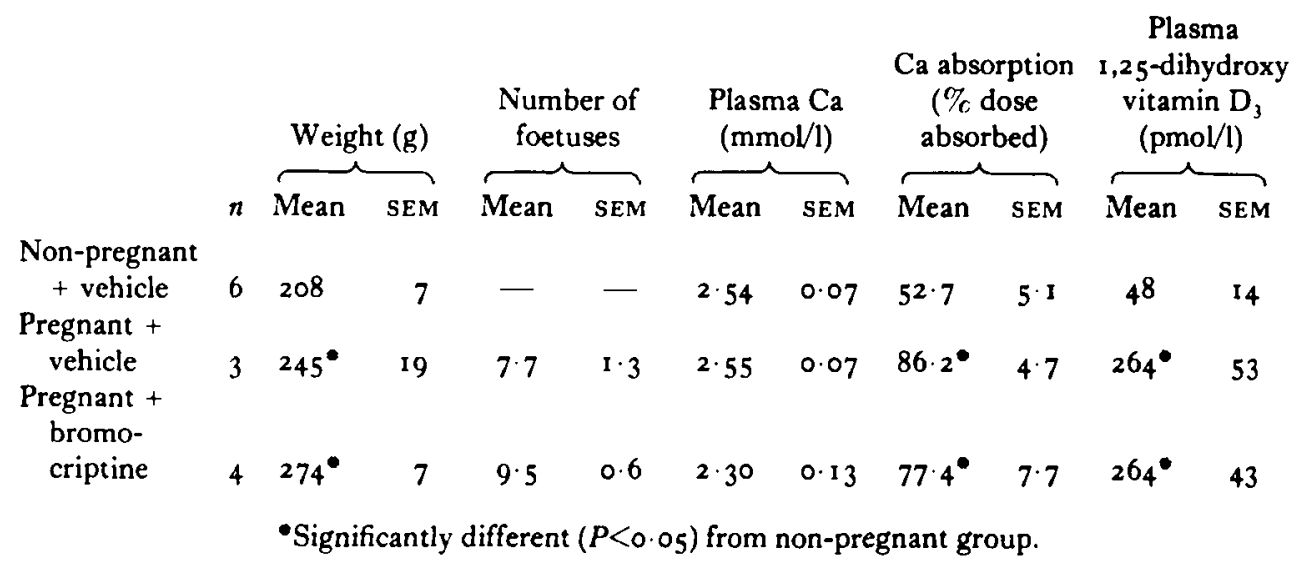


However, since plasma prolactin levels do not rise in the rat (Amenomori et al. 1970), goat, sheep and cow (Cowie et al. 1980) until just before parturition, it is unlikely that prolactin plays an important role in $\mathrm{Ca}$ homoeostasis at this stage of reproduction in those species. This is born out by a study (Table 2) in which bromocriptine treatment was given for $3 \mathrm{~d}$ to block the pre-parturient rise in plasma prolactin levels. The elevations in Ca absorption and plasma $1,25(\mathrm{OH})_{2} \mathrm{D}_{3}$ were almost identical in control and bromocriptine-treated pregnant groups, indicating that the presence of prolactin was not necessary for the adaptive response to occur. However, since prolactin levels rise progressively from the beginning of the third trimester in humans (Del-Pozo et al. 1977) the possibility that prolactin contributes to the response in human pregnancy cannot be excluded.

Calcitonin. Although one report (Swaminathan et al. 1974) indicates that chronic calcitonin treatment may depress $\mathrm{Ca}$ absorption in the pig, the majority of evidence (Krawitt, 1967; Robinson et al. 1969) indicates that calcitonin has no direct effect upon $\mathrm{Ca}$ transport by the gut. However, the possibility of an indirect effect, by inducing secretion of PTH in animals with intact parathyroid glands, cannot be discounted.

Again, the effects of calcitonin on the kidney are limited and controversial. The hormone has only one major action in $\mathrm{Ca}$ metabolism-that of blocking bone resorption, including that induced by $\mathrm{PTH}$ and $\mathrm{r}, 25(\mathrm{OH})_{2} \mathrm{D}_{3}$.

Surprisingly, in spite of a tendency to hypocalcaemia in the later stages of pregnancy, calcitonin levels are actually significantly elevated just before parturition (Samaan et al. 1974). Whilst the physiological advantage of blocking any bone resorption that might otherwise be induced by the elevated PTH concentration is apparent, the reason why the calcitonin levels are elevated remains to be determined. One suggestion is that since gastrointestinal hormones such as gastrin, cholecystokinin-pancreozymin and enteroglucagon, released postprandially, are potent calcitonin secretagogues, and since the food intake before parturition is nearly double the normal intake (Lichtenberger \& Trier, 1979) it seems reasonable to presume that the hyperphagia contributes to the elevated calcitonin levels.

Placental lactogen. Heaney \& Skillman (197x) first suggested that placental lactogen, in addition to its other actions in pregnancy, may play a role in the control of Ca metabolism. It is structurally similar to growth hormone (GH) and prolactin, both of which exert effects upon Ca metabolism by stimulation of the production of $\mathrm{r}, 25(\mathrm{OH})_{2} \mathrm{D}_{3}$ (James et al. 1978 ). Placental lactogen is ideally suited to exert such a role because its levels rise progressively from about mid-term and reflect placental development and, therefore, the increasing demands of the foetus. Moreover, it is present in the plasma in far higher quantities than any other hormone, reaching concentrations measured in micrograms per $\mathrm{ml}$ in humans (Josimovich, 1977) and goats (Cowie et al. 1980).

Human placental lactogen injected at a dose predicted to produce plasma concentrations approximately equal to those seen just before parturition, virtually doubled $\mathrm{Ca}$ absorption in rats (James et al. 1978). 
Subsequent work (Spanos, 1979) has shown that placental lactogen, like prolactin and $\mathrm{GH}$, increases the renal production of $1,25(\mathrm{OH})_{2} \mathrm{D}_{3}$ and indicated that this is probably the mechanism whereby placental lactogen increases $\mathrm{Ca}$ absorption.

Placental lactogen is present in quantities far in excess of any of the other hormones that affect $\mathrm{Ca}$ absorption, and its concentration increases with foetal size. It thus follows that it may well be the hormone which is responsible for the increased $\mathrm{Ca}$ absorption in pregnancy, and thus provides a mechanism whereby intestinal absorption of $\mathrm{Ca}$ can be increased to reflect the increased mineral demand.

It has yet to be determined whether placental lactogen acts directly on the kidney and whether it is responsible for some or all of the extra-renal production of $\mathrm{I}, 25(\mathrm{OH})_{2} \mathrm{D}_{3}$ by the placenta. Notwithstanding, the evidence indicates that placental lactogen deserves to be considered, possibly in conjunction with PTH, as one of the major primary hormonal modulators of $\mathrm{Ca}$ absorption in pregnancy, and suggests a new and important role for the hormone.

Parturient hypocalcaemia. Before proceeding to review the control of $\mathrm{Ca}$ metabolism in lactation it seems pertinent to make reference to this disorder, which largely affects ruminants, usually beginning approximately $24 \mathrm{~h}$ prior to parturition. It is associated with elevated $1,25(\mathrm{OH})_{2} \mathrm{D}_{3}$ and PTH levels (Horst et al. 1978) and a reduced calcitonin content in the blood (Mayer et al. 1975). The aetiology is not certain. One proposal is that the rapid withdrawal of $\mathrm{Ca}$ from the circulation, to be secreted in the colostrum (which in cows has a higher concentration of $\mathrm{Ca}$ than milk), is responsible and that it reflects the failure of the homoeostatic mechanism (Simkiss, 1967).

A simplistic explanation, complementary to that of Simkiss, is as follows. It is recognized that the bovine lactational requirement of $\mathrm{Ca}$ is extremely high (Table $\mathrm{I}$ ) and that this is primarily satisfied by increased absorption of $\mathrm{Ca}$. However, just prior to parturition, in the majority of species, there is an acute reduction of food intake. This results in a reduced secretion of gastrointestinal hormones, which will tend to cause lowered plasma calcitonin levels. The hypocalcaemia resulting from a cessation of $\mathrm{Ca}$ transport from the gut will also lower plasma calcitonin levels, but tend to produce the elevated $1,25(\mathrm{OH})_{2} \mathrm{D}_{3}$ and PTH levels. These obviously do not act upon the gut since there is little $\mathrm{Ca}$ in the gastrointestinal tract. Moreover, the time lag of the skeletal response to these agents is inadequate to satisfy acutely the large demand of the mammary tissue. Accordingly, hypocalcaemia results until such time as the food drive is increased and the hormones exert their effects again on the gastrointestinal tract and, in the short-term, the skeleton.

\section{Adaptive changes during lactation}

The $\mathrm{Ca}$ demand of lactation is greater than that of pregnancy (Table 1 ) and, moreover, increases progressively until weaning (Baksi \& Anderson, 1971). This is paralleled by alterations in the adaptative processes, similar to those observed in pregnancy but larger in magnitude: 
(1) A reduction in urinary Ca excretion (Retallack et al. 1977).

(2) An increase in food intake (Lichtenberger \& Trier, 1979).

(3) An increase in intestinal absorption of $\mathrm{Ca}$ (Fournier \& Susbielle, 1952).

In spite of these, skeletal demineralization has been reported in lactating rats (Warnock \& Duckworth, 1944), sheep (Braithwaite, 1978) and humans (Atkinson \& West, 1970), indicating a failure to match the demand of lactation. This may be a matter of some concern in repeated pregnancies or prolonged lactations.

The reduction in urinary $\mathrm{Ca}$ excretion is partly due to the reduced filtered load, consequent upon the modest lowering of plasma $\mathrm{Ca}$ frequently seen in this situation, and also the conservative effect of the resultant increased PTH level (Samaan et al. 1974; Retallack et al. 1977) upon the kidney. However, the amount of $\mathrm{Ca}$ conserved is so small in comparison with the $\mathrm{Ca}$ secreted in the milk that, with the possible exception of humans (Table I, Retallack et al. 1977), it contributes probably less than $5 \%$ of milk $\mathrm{Ca}$.

The increase in food intake is well recognized, with up to a quadrupling of food intake being recorded in rats (Lichtenberger \& Trier, 1979). This has two advantages to the animal, it increases the amount of $\mathrm{Ca}$ available for absorption and by its bulk contributes to the intestinal hypertrophy that facilitates increased absorption.

The mechanism of the increase in food intake remains uncertain. Our studies (C. J. Robinson and D. Stephenson, unpublished results) indicate that prolactin injected twice daily can induce a modest $20 \%$ increase in food intake in virgin female rats, but nothing approaching the $300 \%$ increase observed in the lactating female rat. Admittedly, in our studies the animals employed were virgin rats so that the possibility of interactions with other hormones could not be excluded, nor could the effect of suckling itself (Cotes \& Cross, 1954) which may be important in generating such a drive.

The increase in $\mathrm{Ca}$ absorption is the most important factor responsible for satisfying the majority of the lactational drain of Ca. Recent evidence (Halloran \& DeLuca, 1980) would suggest that the response can be divided into two parts, that attributable to intestinal hypertrophy, which may be of mechanical or hormonal origin, and that attributable to facultative alterations in the concentration of $1,25(\mathrm{OH})_{2} \mathrm{D}_{3}$ in the blood. At present the proportional contribution of these two remains to be defined, but it is now quite clear that $1,25(\mathrm{OH})_{2} \mathrm{D}_{3}$ approximates to the so-called 'endogenous factor' (Nicolaysen, 1943) which alters $\mathrm{Ca}$ absorption to match body demands. As the production of $1,25(\mathrm{OH})_{2} \mathrm{D}_{3}$ by the kidneys is sensitive to alterations in a number of putative controlling hormones, there has been some doubt as to which agent, or agents, was actually responsible for the elevated levels in lactation. The subsequent section deals with the possible candidates of this role and others that contribute to the maintenance of $\mathrm{Ca}$ homoeostasis in lactation.

\section{Alteration of Ca-regulating hormones during lactation}

Calcitonin. The levels of calcitonin are elevated during lactation (Toverud et al. 
1978). Again, the cause for this is uncertain in view of the normocalcaemic or even slightly hypocalcaemic state. However, the hyperphagic-stimulated release of calcitonin secretagogues from the gastrointestinal tract, in concert with the transient post-prandial hypercalcaemia resulting from the increased absorption of $\mathrm{Ca}$, may well contribute significantly to this response. Studies in animals given limited rations will allow definition of this putative axis.

If calcitonin is present in increased concentrations in the blood, is it fulfilling any physiological role? Our experimental studies (Table 3 ) show that animals deprived of their thyroids but with auto-transplanted parathyroid glands (calcitonin deficient) had significantly less $\mathrm{Ca}$ in their skeleton, and their $\mathrm{Ca}$ absorption was reduced, compared with intact controls in whom the Ca requirement for lactation was obtained from the diet rather than the maternal skeleton (Lewis et al. 1971). Thus, calcitonin has indeed an important physiological role-that of protecting the skeleton from the demineralizing actions of PTH, whilst permitting its other actions on $\mathrm{Ca}$ transport, including that in the gut, to go unhindered.

Parathyroid hormone. Certainly PTH levels are elevated during early lactation (Samaan et al. 1974; Retallack et al. 1977). However, there is some controversy concerning later lactation where one report (Cushard et al. 1972) indicates that PTH falls towards normal levels whilst lactation is still progressing, thus casting doubts on the contribution of PTH to this adaptive response. Undoubtedly, the elevated PTH levels are responsible for the reduction in urinary $\mathrm{Ca}$ in lactation, and may also contribute to skeletal demineralization, since the skeletons of parathyroidectomized animals are heavier at the end of lactation than those of comparable controls (Bodansky \& Duff, 194I). PTH does stimulate the production of $I, 25(\mathrm{OH})_{2} \mathrm{D}_{3}$ by the kidney (Fraser \& Kodicek, 1973) and may well contribute to the elevated levels observed in lactation. However, in the light of the observation that PTH levels can fall whilst lactation is still progressing and recent experimental

Table 3. Effect of calcitonin deficiency on bone constituents and calcium absorption in lactating rats

(Mean values with their standard errors)

\begin{tabular}{|c|c|c|c|c|c|c|c|c|c|c|c|}
\hline & & \multicolumn{6}{|c|}{ Femur (mg) } & \multicolumn{4}{|c|}{$\begin{array}{c}\text { Ca absorption } \\
\text { (\% dose absorbed) }\end{array}$} \\
\hline & & \multicolumn{2}{|c|}{ Weight } & \multicolumn{2}{|c|}{$\mathrm{Ca}$} & \multicolumn{2}{|c|}{ Phosphorus } & \multicolumn{2}{|c|}{ Duodenum } & \multicolumn{2}{|c|}{ Jejunum } \\
\hline & $n$ & Mean & SEM & Mean & SEM & Mean & SEM & Mean & SEM & Mean & SEM \\
\hline $\begin{array}{l}\text { Control } \\
\text { Calcitonin- }\end{array}$ & 7 & $570 \cdot 7$ & $16 \cdot 6$ & $101 \cdot 8$ & $3 \cdot 7$ & $53 \cdot 6$ & 3.0 & $98 \cdot 1$ & 0.4 & $40 \cdot 1$ & $3 \cdot 2$ \\
\hline deficient & 9 & 518.9 & $5 \cdot 5$ & $91 \cdot 3$ & I. 3 & $43 \cdot 7$ & $1 \cdot 0$ & $96 \cdot 6$ & 0.6 & $29 \cdot 7$ & $1 \cdot 7$ \\
\hline $\begin{array}{l}\text { Difference } \\
\text { Significance of } \\
\text { difference } \\
(P)\end{array}$ & & $5 \mathrm{I} \cdot 8$ & 15.2 & 10.5 & 34 & 9.9 & $2 \cdot 8$ & $I \cdot 5$ & 0.7 & 10.4 & 3.4 \\
\hline
\end{tabular}


Table 4. Effect of bromocriptine and prolactin ( $0.5 \mathrm{mg}$ twice daily for $3 \mathrm{~d}$ ) in lactating rats*

(Mean values with their standard errors)

\begin{tabular}{|c|c|c|c|c|c|c|c|c|c|c|c|c|}
\hline & & $\begin{array}{r}\text { Plasma } \\
\text { (mmol }\end{array}$ & & ${ }_{(\%}^{\mathrm{C}}$ & $\begin{array}{l}\text { a absorp } \\
\text { dose abs }\end{array}$ & $\begin{array}{l}\text { tion } \\
\text { orbed) }\end{array}$ & & $\begin{array}{l}\text { 25-dihyd } \\
\text { itamin D } \\
\text { (pmol/) }\end{array}$ & $\begin{array}{l}\text { lroxy } \\
\text { 1) } \\
\text { 1) }\end{array}$ & & $\begin{array}{l}\text { Parathyr } \\
\text { rmone }(\mu\end{array}$ & $\begin{array}{l}\text { roid } \\
\text { lg eq/l) }\end{array}$ \\
\hline & $n$ & Mean & SEM & $n$ & Mean & SEM & $n$ & Mean & SEM & $n$ & Mean & SEM \\
\hline $\begin{array}{l}\text { Non-lactating } \\
\text { controls } \\
\text { Lactating }\end{array}$ & 9 & $2 \cdot 53$ & 0.02 & 9 & $17 \cdot 4$ & 1. 5 & 3 & $62 \cdot 5$ & $4 \cdot 8$ & 10 & 0.205 & 0.032 \\
\hline $\begin{array}{l}\text { controls } \\
\text { Lactating + }\end{array}$ & 8 & $2 \cdot 4^{a}$ & 0.03 & 8 & $25 \cdot 3^{a}$ & $2 \cdot 8$ & 4 & $95 \cdot 7^{a}$ & 8 & 9 & $0.3^{8} 3^{a}$ & 0.053 \\
\hline $\begin{array}{l}\text { bromocriptine } \\
\text { Lactating + } \\
\text { bromocriptine } \\
\text { + prolactin }\end{array}$ & 7 & $2 \cdot 5^{8}$ & 0.03 & 7 & $16 \cdot 2^{b}$ & $2 \cdot 9$ & 4 & $60 \cdot 8^{b}$ & 154 & 9 & 0.374 & 0.063 \\
\hline + prolactin & 7 & $2 \cdot 62^{\circ}$ & 0.03 & 8 & $25 \cdot 7$ & $5 \cdot 6$ & 4 & $70 \cdot 45$ & $15 \cdot 4$ & 10 & 0.484 & 0.073 \\
\hline
\end{tabular}

results on the role of prolactin in $\mathrm{Ca}$ absorption (see p. $\mathrm{I}_{78}$ ), it seems unlikely that PTH is the sole controlling hormone regulating $\mathrm{Ca}$ absorption in lactation.

PTH does not seem to affect the transfer of $\mathrm{Ca}$ in the mammary gland in the goat (Hove \& Tollman, I98I). Moreover, rats deprived of their parathyroid glands have been shown to be able to reproduce and suckle their young almost normally (Fry et al. 1979), the only impairment of pup growth appearing between days 6 and 12 of lactation. It thus follows that whilst PTH should be present for optimal reproductive capacity and litter growth, its presence may not be essential for lactation to proceed and for an adequate supply of $\mathrm{Ca}$ to be provided to the mother and foetus.

Prolactin. This appears to be the most likely candidate for the role of primary controller of $\mathrm{Ca}$ absorption mediated by $1,25(\mathrm{OH})_{2} \mathrm{D}_{3}$ during lactation for the following reasons:

(I) Prolactin has a direct stimulatory action on renal $\mathrm{I}, a$-hydroxylase (MacIntyre et al. 1979) and it causes rapid elevation of plasma $\mathrm{r}, 25(\mathrm{OH})_{2} \mathrm{D}_{3}$ levels in intact animals (Spanos et al. 1976).

(2) Prolactin has been shown to stimulate $\mathrm{Ca}$ absorption in the rat both in vitro (Mainoya, 1975) and in vivo (James et al. 1977).

(3) Prolactin is ideally suited to regulate the supply of Ca during lactation as it is the only lactogenic hormone, with the exception of $\mathrm{GH}$ in ruminants (Hart, 1973), whose levels are regulated by suckling (Cowie \& Tindal, I97I) and lactational demand. 
The following studies (Robinson et al. 1982), using the agent bromocriptine which suppresses prolactin secretion, provide evidence which supports this suggestion. Lactating rats were divided into two groups, one of which received bromocriptine treatment for $3 \mathrm{~d}$. Appropriate control groups were also included. At the end of the treatment $\mathrm{Ca}$ absorption and levels of plasma $\mathrm{Ca}, 1,25(\mathrm{OH})_{2} \mathrm{D}_{3}$ and PTH were measured. The results (Table 4 ) show that $\mathrm{Ca}$ absorption increased during lactation, confirming previous observations and, moreover, that the levels of both $1,25(\mathrm{OH})_{2} \mathrm{D}_{3}$ and PTH were elevated. However, treatment with bromocriptine lowered $\mathrm{Ca}$ absorption and $\mathrm{I}, 25(\mathrm{OH})_{2} \mathrm{D}_{3}$ levels to normal, whilst PTH levels remained elevated.

The results, therefore, indicate that the increased $\mathrm{Ca}$ absorption seen in the lactating rat is caused by the elevated levels of prolactin. Further evidence of this is provided by the fact that exogenously administered prolactin prevented the fall in $\mathrm{Ca}$ absorption and $1,25(\mathrm{OH})_{2} \mathrm{D}_{3}$ levels in rats treated with bromocriptine. Thus these results strongly suggest that prolactin, rather than PTH, is the major hormone controlling $\mathrm{Ca}$ absorption in the lactating rat.

\section{Hypothesis}

Pregnancy and lactation present considerable $\mathrm{Ca}$ stresses on maternal homoeostatic mechanisms, the stress due to lactation being considerably greater in the majority of mammals. The $\mathrm{Ca}$ demands are largely satisfied in four ways:

(I) By a facultative reduction in urinary Ca excretion.

(2) By increased food intake.

(3) By intestinal hypertrophy and increase of mucosal area.

(4) By a facultative increase in the intestinal absorption of $\mathrm{Ca}$, consequent upon elevated levels of $1,25(\mathrm{OH})_{2} \mathrm{D}_{3}$.

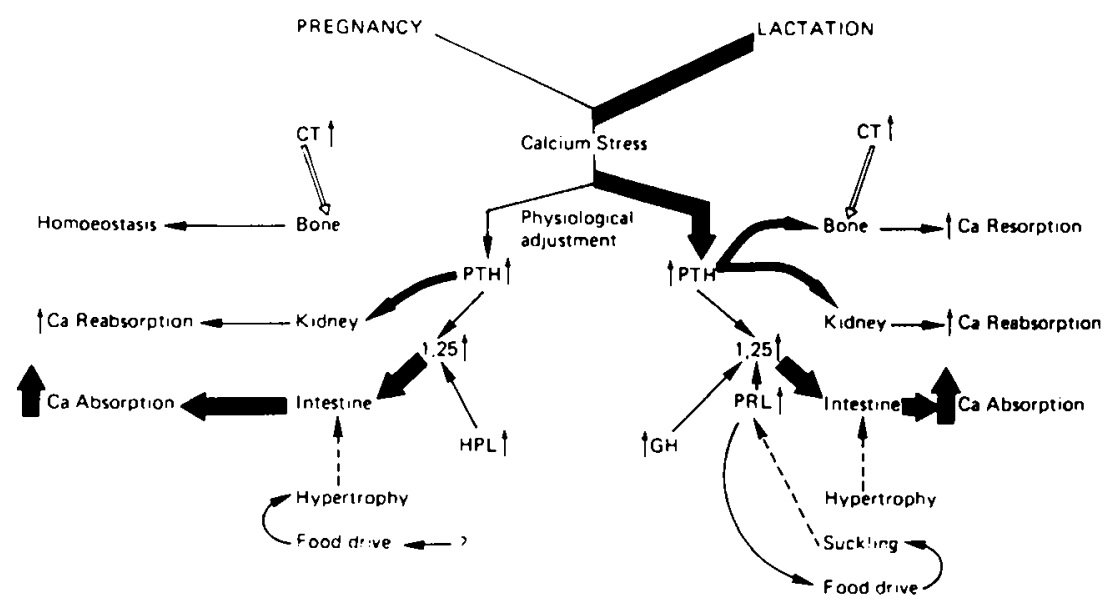

Fig. 1. The proposed hormonal control of calcium metabolism in pregnancy and lactation. CT, calcitonin; PTH, parathyroid hormone; HPL, human placental lactogen; GH, growth hormone; PRL, prolactin; $1,25,1,25$-dihydroxy vitamin $\mathrm{D}_{3}$. 
In pregnancy the demand (Fig. I) is satisfied by all four mechanisms. In the case of point (4), the increased synthesis of $1,25(\mathrm{OH})_{2} \mathrm{D}_{3}$ is mediated by PTH and placental lactogen. This gives the latter hormone, whose levels rise as pregnancy progessses, a new and important physiological role.

In lactation. Again, all mechanisms contribute to satisfy the demand for $\mathrm{Ca}$ and to a greater absolute extent than in pregnancy. The elevated concentration of $1,25(\mathrm{OH})_{2} \mathrm{D}_{3}$ which causes the increased absorption of $\mathrm{Ca}$ may in part be controlled by PTH, but the main controlling hormone is prolactin whose plasma levels reflect the lactational demand. It is thus suggested that this represents a major new physiological role for prolactin in lactation.

\section{REFERENCES}

Amenomori, Y., Chen, C. L. \& Meites, J. (1970). Endocrinology 86, 506.

Atkinson, P. J. \& West, R. R. (1970). J. Obstet. Gynaec., Br. Commonw. 77, 555.

Baksi, S. N. \& Anderson, R. R. (1971). Proc. Soc. exp. Biol. Med. 137, 215.

Bodansky, M. \& Duff, V. B. (I94I). F. Nutr. 21, 235.

Bonjour, J. P., Preston, C., Rizzoli, R. \& Fleisch, H. (1978). In Endocrinology of Calcium Metabolism, p. I 72 [D. H. Copp and R. V. Talmage, editors]. Amsterdam: Excerpta Medica.

Boyne, R., Fell, B. F. \& Robb, I. (1 966). F. Physiol. 183, 570.

Braithwaite, G. D. (1978). Br. F. Nutr. 39, 213.

Braithwaite, G. D., Glascock, R. F. \& Riazuddin, SH. (1969). Br. F. Nutr. 23, 827.

Braithwaite, G. D., Glascock, R. F. \& Riazuddin, SH. (1970). Br. F. Nutr. 24, 66 1.

Capen, C. C., Koestner, A. \& Cole, C. R. (1965). Lab. Invest. 14, 1673.

Cotes, P. M. \& Cross, B. A. (1954). 7. Endocr. 10, 363 .

Cowie, A. T., Forsyth, I. A. \& Hart, I. C. (1980). In Hormonal Control of Lactation, p. Io9, Monographs on Endocrinology. Berlin: Springer Verlag.

Cowie, A. T. \& Tindal, J. S. (1971). The Physiology of Lactation. Monographs of the Physiological Society, no. 22. London: Edward Arnold.

Craft, I. L. (1970). Clin. Sci. 38, 287.

Cushard, W. G., Creditor, M. A., Canterbury, J. M. \& Reiss, E. (1972). F. clin. Endocr. 34, 767.

Del-Pozo, E., Hiba, J., Lancranjan, I. \& Kunzig, H. J. (1977). In Prolactin and Human Reproduction [P. G. Crosignani and C. Robyn, editors]. New York: Academic Press.

Field, A. C. (1981). Proc. Nutr. Soc. 40, 267.

Fournier, P. \& Susbielle, H. (1952). Y. Physiol., Paris 44, 123.

Fraser, D. R. \& Kodicek, E. (1973). Nature, New Biol. 24I, I63.

Fry, J. M., Curnow, D. H., Gutteridge, D. H. \& Retallack, R. W. (1979). F. Endocr. 82, 323.

Goss, D. A. (1 962). Obstét. Gynéc. 20, 199.

Gueguen, L. \& Perez, J. M. (1981). Proc. Nutr. Soc. 40, 273.

Halloran, B. P. \& DeLuca, H. F. (1980). Am. F. Physiol. 239, E64.

Harding, J. D. \& Cairnie, A. B. (1 975). Cell. Tiss. Kinet. 8, 135.

Hart, I. C. (1973): Y. Endocr. 57, 179.

Hart, 1. C., Bines, J. A. \& Morant, S. V. (1978). J. Dairy Sci. 62, 270.

Heaney, R. P. \& Skillman, T. G. (1971). Y. Clin. Endocr. 33, 66r.

Horst, R. L., Jorgensen, N. A. \& DeLuca, H. F. (1978). Am. F. Physiol. 235, E634.

Hove, K. \& Tollman, R. (I981). F. Endocr. 89, 297.

Hummel, F. C., Sternberger, H. R., Hunscher, H. A. \& Macy, I. G. (1936). J. Nutr. $11,235$.

James, M. F., Makeen, A. M., Foley, S., Stevens, J. \& Robinson, C. J. (1977). F. Endocr. 75, ${ }_{53} \mathrm{P}$.

James, M. F., Spanos, E., Robinson, C. J., Makeen, A. M., Snowball, S., Colston, K. W., Hillyard, C. \& MacIntyre, I. (1978). F. Endocr. 79, 38 P. 
Josimovich, J. B. (1977). In Endocrinology of Pregnancy, p. 191 [F. Fuchs and A. Klopper, editors]. New York: Harper and Row.

Kaufman, S. (1981). F. Physiol. 318, 9.

Krawitt, E. L. (1967). Proc. Soc. exp. Biol. Med. 125, 1084.

Lewis, P., Rafferty, B., Shelley, M. \& Robinson, C. J. (I971). J. Endocr. 49, ix.

Lichtenberger, L. M. \& Trier, J. S. (1979). Am. F. Physiol. 237, E98.

MacIntyre, I., Brown, D. J. \& Spanos, E. (1979). In Vitamin D Basic Research and its Clinical Application, p. 523 [A. W. Norman, K. Schaefer, D. von Herrath, H. G. Grigoleit, J. W. Coburn, H. F. DeLuca, E. B. Mawer and T. Suda, editors]. New York: Walter de Gruyter.

MacIntyre, I. \& Robinson, C. J. (1969). Ann. N.Y. Acad. Sci. 162, 865.

Mainoya, J. R. (1975). Endocrinology 96, I 165.

Makeen, A. M. (I980). Studies of the effects of hormones upon the metabolism of calcium and other minerals in experimental animals and man. PhD Thesis, University of Newcastle upon Tyne.

Mayer, G. P., Blum, J. W. \& Deftos, L. J. (1975). Endocrinology 96, 1478.

Nicolaysen, R. (1943). Acta. Physiol. Scand. 5, 200.

Nordin, B. E. C. \& Peacock, M. (r g69). Lancet ii, r 280.

Norman, A. W. (1978). In Vitamin D, p. 93 [D. E. M. Lawson, editor]. London and New York: Academic Press.

Payne, J. M. (1964). Vet. Rec. 16, I 275.

Pitkin, R. M. (1975). Am. J. Obstet. Gynecol. 121, 724.

Puschett, J. B., Beck, W. S., Jelonek, A. \& Fernandez, P. C. (1974). f. clin. Invest. 53, 756.

Retallack, R. W., Jefferies, M., Kent, G. N., Hitchcock, N. E., Gutteridge, D. H. \& Smith, M. (1977). Calcif. Tiss. Res. 22, I 42.

Robinson, C. J. (1974). Clinics Endocr. Metab. 3, 389.

Robinson, C. J., Matthews, E. W. \& MacIntyre, I. (1969). In Les Tissus Calcifiés, Proceedings of the V European Symposium, p. 279 [G. Milhaud, M. Owen and H. J. J. Blackwood, editors]. Paris: S.E.D.E.S.

Robinson, C. J., Spanos, E., James, M. F., Pike, J. W., Haussler, M. R., Makeen, A. M., Hillyard, C. J. \& MacIntyre, I. (I982). F. Endocr. 94, 443.

Samaan, N. A., Wigoda, C. \& Castillo, S. C. (1974). In Endocrinology, 1973, p. 364 [S. Taylor, editor]. London: W. Heinemann.

Schachter, D., Dowdle, E. B. \& Schenker, H. (1960). Am. Y. Physiol. 198, 263.

Scott, D. \& McLean, A. F. (I98I). Proc. Nutr. Soc. 40, 257.

Simkiss, K. (1 967). In Calcium in Reproductive Physiology. London: Chapman and Hall.

Spanos, E. (1979). The regulation of 1,25 -dihydroxycholecalciferol production by the kidney. $\mathrm{PhD}$ Thesis, University of London.

Spanos, E., Barrett, D. \& MacIntyre, I. (1978). Nature, Lond. $273,246$.

Spanos, E., Colston, K. W., Evans, I. M. A., Galante, L. S., MacCauley, S. J. \& MacIntyre, I. (1976). Molec. Cell Endocr. 5, 163.

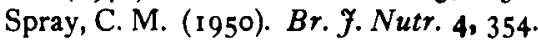

Swaminathan, R., Ker, J. \& Care, A. D. (1974). F. Endocr. 61, 83.

Toverud, S. U., Cooper, C. W. \& Munson, P. L. (1978). Endocrinology 103, 472.

Warnock, G. M. \& Duckworth, J. (1944). Biochem. F. 38, 220.

Weisman, Y., Harell, A., Edelstein, S., David, M., Spirer, Z. \& Golander, A. (1979). Nature, Lond. 281, 317 . 